\title{
BENTUK TANGGUNGJAWAB NEGARA TERHADAP HAK KONSTITUSIONAL ANAK TERLANTAR: ANALISIS TEORI KONTRAK SOSIAL
}

\author{
Teguh Wicaksono \\ Prodi Hukum, Fakultas Ilmu Sosial dan Humaniora, \\ Universitas Ibrahimy, Situbondo Jawa Timur \\ Email: wichax82@gmail.com
}

\begin{abstract}
Abstraks
Keberadaan anak terlantar masih menjadi persoalan serius dan harus segera di atasi. Berdasarkan data Kemensos pada bulan Desember 2020, keberadaan anak terlantar sejumlah 67.368 orang tentu data tersebut belum menggambarkan secara baik jumlah keseluruhan dari anak-anak yang terlantar secara keseluruhan sehingga jumlahnya sangat mungkin lebih banyak dari data Kemensos tersebut. Hal ini menunjukkan upaya pemerintah selama ini belum maksimal dalam upaya mengatasi persoalan di atas. Sehingga diperlukan penanganan yang serius dari pemerintah guna mengambalikan hak-hak konstitusional anak terlantar sebagaimana hak tersebut telah ditegaskan Pasal 34 (1) UUD 1945. Hal ini menegaskan bahwa, terdapat ketentuan kewajiban negara agar melindungi serta menjamin terpenuhinya hak konstitusional daripada anak terlantar di atas. Untuk itu artikel ini akan mengkaji terkait bentuk pertanggungjawaban pemerintah/negara terhadap pemenuhan hak dasar anak tersebut di atas. Selain itu, artikel ini mengakaji mekanisme negara untuk mengatasi persoalan di atas. Artikel ini menggunakan tipe penelitian teoritis di mana teori kontrak sosial digunakan untuk menganalisis bentuk pertanggungjawaban pemerinatah/negara terhadap hak konstitusional warga negara secara luas.
\end{abstract}

Kata Kunci : Tanggung Jawab Negara, Hak Konstitusional, Anak Terlantar.

\begin{abstract}
The existence of abandoned children is still a serious problem and must be addressed immediately. Based on data from the Ministry of Social Affairs in December 2020, the presence of neglected children of 67,368 people, of course, this data does not adequately describe the total number of neglected children as a whole, so the number is very likely to be higher than the Ministry of Social data. This shows that the government's efforts so far have not been maximal in efforts to overcome the
\end{abstract}


problems above. So that serious handling is needed from the government to restore the constitutional rights of neglected children as stated in Article 34 (1) of the 1945 Constitution. This confirms that there are provisions for the state's obligation to protect and ensure the fulfillment of the constitutional rights of neglected children above. For this reason, this article will examine the forms of government/state accountability for the fulfillment of the children's basic rights mentioned above. In addition, this article examines state mechanisms to address the above problems. This article uses a theoretical type of research in which social contract theory is used to analyze the form of government/state accountability for the constitutional rights of citizens broadly.

Keywords : Tate Responsibilities, Constitutional Rights, Abandoned Children.

\section{PENDAHULUAN}

\section{A. Latar Belakang}

Anak adalah mandat pada saat yang sama anak adalah hadiah Allah SWT, di dalam diri seorang anak melekat padanya berupa harkat, martabat, serta hak dasar lainnya yang harus di jaga serta dihormati dan mendapatkan pengakuan tertinggi. Hak anak adalah bagian yang tak dapat dipisahkan dari Konstitusi Republik Indonesia (UUD 1945) serta Konvensi PBB mengenai hak anak. Disisi kehidupan bangsa, anak merupakan harapan bangsa serta generasi penerus masa depan bangsa, oleh sebab itu, setiap jiwa/raga anak memiliki hak untuk kehidupan, bertumbuh, serta berkembang, lalu berpartisipasi dalam kehidupan berbangsa bernegara dan berhak untuk dilindungi dari kekerasan dan diskriminasi. ${ }^{1}$

Anak memiliki nilai yang luar biasa baik dipandang berdasarkan perspektif kehidupa sosial, sisi budaya, kondisi ekonomi, serta politik, dan hukum, sedangkan dari sudut pandang berlangsungnya dari keturunan keluarga, suku, dan bangsa. Jika dilihat dalam konteks sosial anak sebagai suatu kehormatan bagi keluarga, dari sisi budaya memandang anak adalah kekayaan yang harus diperhatika, pada saat yang sama anak adalah simbol dari kesuburan seseorang, dari sisi politik anak adalah penerus bangsa, dari ekonomi anak memunculkan harapan terkait pembagian rezeki dari Tuhan. Sudut pandang hukum, anak berhak mendapatkan tempat yang strategis

\footnotetext{
${ }^{1}$ Imam Sukadi, Tanggung Jawab Negara Terhadap Anak Terlantar Dalam Operasionalisasi Pemerintah Di Bidang Perlindungan Hak Anak.de Jure, Jurnal Syariah dan Hukum.Volume 5 Nomor 2, Desember 2013. hlm, 2
} 
baik sebagai keturunan maupun sebagai subyek hukum dengan semua yang melekat pada diri seorang anak sebagai manusia. ${ }^{2}$

Anak terlantar identik dengan kemiskinan sehingga dengan banyaknya anak terlantar akan berdampak pada meningkatnya angka kemiskinan di di Indonesia. Pembiaran anak terlantar adalah suatu bagian pelanggaran HAM. ${ }^{3}$ Sebab anak-anak yang hidup pada kondisi terlantar sekalipun maka ia tetap melekat pada diirinya suatu hak yang sama dengan kebayakan anak pada umumnya baik hak hidup dalam kehidupan, tumbuh, serta berkembang dan dapat berpartisipasi sejalan dengan martabatnya sebagai manusia, serta dan merasa dilindungi dari kekerasan dan sejenisnya. ${ }^{4}$ Esensi dari negara hukum yang berkonstitusi adalah perlindungan terhadap hak asasi manusia. Oleh karena itu, isi dari setiap konstitusi tersebut dapat dijelaskan sebagai berikut, negara merupakan organisasi kekuasaan berdasarkan kedaulatan rakyat, agar kekuasaan ini tidak liar maka perlu dikendalikan dengan cara disusun, dibagi dan dibatasi, serta diawasi baik oleh lembaga pengawasan yang mandiri dan merdeka maupun oleh warga masyarakat, sehingga tidak terjadi pelanggaran terhadap hak-hak asasi manusia. ${ }^{5}$

Negara/pemerintah wajib hukumnya guna memberi jaminan terhadap HAM, sesuai dengan mandat konstitusi Pasal 34 (1) yang artinya, anak-anak yang terabaikan di pelihara oleh negara, negara wajib hadir sebagai pelindung dan sekaligus bertanggung jawab dalam penanganan memberikan bimbingan bagi anaktersebut. Pada dasarnya hak konstitusional adalah hak semua warga negara di seluruh bumi Indonesia yang harus dijamin akan pemenuhan hak-hak tersebut oleh Negara. ${ }^{6}$

Serangkaian aturan untuk melindungi dan menjamin HAM khususnya terkait hak anak di Indonesia sudah ada. Misalnya, lama sebelum mengesahkan convensi

\footnotetext{
2Fifk Wiryani, "Perlindungan Hukum Bagi Pekerja Anak", Jurnal Legality, Vol. 11 No. 2 September 2003Februari 2004, hlm. 288

${ }^{3}$ Ketentuan UU No. 35 Tahun 2014 Tentang Perlindungan Anak Pasal 2

${ }^{4}$ Imam Sukadi, Op Cit. hlm, 3

5 Ibad, S. Hukum Administrasi Negara Dalam Upaya Penyelenggaraan Pemerintahan Yang Baik. Hukmy: Jurnal Hukum. Vol. 1, (1) April 2021. https://doi.org/10.35316/hukmy.2021.v1i1.55-72 ${ }_{6}^{6}$ Jihan Thania Damayanti Safitri. Dkk. Tanggung jawab negara terhadap hak konstitusional anak terlantar di indonesia.Lex Privatum Vol. IX/No. 4/Apr/EK/2021. hlm, 4
} 
terhadap hak anak (CRC) pada 1990, negara telah menetapkan UU No. 4/1979 yang mengatur tentang kesejahteraan anak. Maka sudah seharusnya hal tersebut menjadi referensi dalam membuat kebijakan-kebijakan terhadap perlindungan anak-anak khsususnya anak terlantar, namun pada kenyataannya keberadaan anak di bumi Indonesia masih mendapati berbagai persoalan dari sisi penegakan HAM. Sampai akhirnya Indonesia meratifkasi Konvensi pada Konvensi hak-hak asasi anak (Konvensi pada rights of Child), Konvensi diratifikaasi dengan Dekrit Presiden No. 36/1990 tetapi hal tersebut juga tidak lantas menjadi solusi terhadap problematika anak di Indonesia. Kemudian setelah Ratifkasi KHA Indonesia memberlakukan UU No.3/1997 yang mengatur tentang praktik Peradilan khusus anak dan kemudian diubah dengan uu No. 23/2002 yang juga mengalami perubahan dengan uu No. $35 / 2014 .^{7}$

Pasal 2 uu No. 23/2002 dan sudah di ganti uu No.35/2014 yang mengatur terkait Perlindungan dan keberadaan Anak dengan jelas bahwa konteks dasar adanya perlindungan bagi anak dalam aturan tersebut, yaitu tidak adanya perilaku diskriminasi, kehidupan yang baik untuk anak, prinsip dasar kehidupan yang memuat hak untuk hidup harus digunakan sebagai dasar untuk melindungi anak. Ini dapat diartikan bahwa regulasi yang ada harus disandarkan pada subtansi convensi tersebut di atas. ${ }^{8}$

Akan tetapi masalah utama yang pokok yaitu kenapa hukum yang ada dan berlaku ini tidak dapat memberikan perlindungan terhadap anak jalanan yang masuk dalam kelompok terlantar. PP No. 2/1988 Pasal 6 (2) menyebut Anak di Indonesia bisa dijadikan sebagai anak angkat atau asuh, dengan cara di adopsi untuk meningkatkan keterampilan pada diri anak. Melalui Kementerian Sosial, serta menjadikan anak memiliki kesehatan mental agar dapat kembali pada kondisi anak itu normal guna bisa tumbuh serta dapat mengembagkan hidupnya dengan baik ditengah-tengah masyarakat umum. Negara dengan Ideologinya Pancasila, dan menganut nilai luhur dan prikemanusiaan, serta dalam ketentuan Konstitusi di

\footnotetext{
${ }^{7}$ Imam Sukadi, Tanggung Jawab Negara Terhadap Anak Terlantar Dalam Operasionalisasi Pemerintah Di Bidang Perlindungan Hak Anak.de Jure, Jurnal Syariah dan Hukum.Volume 5 Nomor 2, Desember 2013. hlm, 118

${ }^{8}$ Ibid,

238 HUKMY|Jurnal Hukum
} 
tegaskan dalam Pasal 34 (1), menyebutkan bahwa:9 "kaum miskin/fakir dan anak yang berada dalam keadaan terlantar dilindungi dengan Konstitusi, tujuan dari Negara pada anak dengan kondisi terlantar agar bisa bertumbuh serta berkembang sebagaimana seharusnya guna bisa berpartisipasi sesuai dengan mandat Konstitusi. ${ }^{10}$

Mandat konstitusi, anak-anak miskin dan terlantar berhak dikelola dan diperlihara oleh negara, sebab negara bertanggungjawab untuk memelihara dan melindungi mereka. Dalam teori kontrak sosial, hak dan tanggung jawab lahir atas dasar perjanjian dan kesepakatan antara individu dengan negara di awal mula pembentukan suatu negara. Dalam teori kontrak sosial dari John Locke, kontrak sosial merupakan pemberian otoritas dari politik agar ada batasan otoritas pada subjek serta kewenangan tiap penguasa untuk insan manusia secara alami terlahir dengan bebas dan berada pada kedudukan sama dimata hukum. ${ }^{11}$ Baginya tak seorangpun mengusai kekuasaan politik jika tidak terdapat dukungan dari masyarakat. jelas ini bermakna bahwa dasarnya semua pekerjaan atau aktivitas orang dasari dengan persetujuan dari pemerintah, akan tetapi, dalam pemerintahan yang berdaulatlah orang-orang bebas berfikir sebagai warga negara. Dan negara/pemerintah punya kewajiban untuk menjaga rakyat serta melindunginya sesuai dengan konteks dasar HAM bahwa setiap warga negara bebas dari diskriminasi. ${ }^{12}$

\section{B. Batasan Masalah}

Berangkat dari latar belakang persoalan di atas, maka penulis membatasi pokok permasalahan yang akan dikaji dalam artikel ini adalah bagaimana bentuk pertanggungjawaban negara terhadap pemenuhan hak dasar anak yang berada pada kondisi terabaikan atau terlantar. Selain itu, artikel ini mengakaji mekanisme atau strategi negara/pemerintah guna mengatasi persoalan hak daripada anak tersebut.

${ }_{9}$ Zulfahmi, Perlindungan Terhadap Hak Konstitusional Anak Terlantar, JOM Fakultas Hukum, Vol. 1 Nomor 2, Oktober 2014. hlm, 2

${ }^{10}$ Ibid,

11Daya Negri Wijaya. Kontrak Sosial MenurutThomas Hobbes Dan John Locke. JSPH Volume 1, Nomor 2, Desember 2016.hlm. 187

12Ibid, hlm, 189 
Tujuan dari penulisan artikel ini adalah untuk mengetahui bentuk-bentuk pertanggungjawaban negara dalam memenuhi hak warga negaranya terutama pada hak anak. Tujuan lain untuk mengetahui da menganalisa mekanisme dan atau strategi yang dilakukan pemerintah dalam menyelesaika persoalan di atas.

\section{Motode Penelitian}

Artikel ini menggunakan tipe penelitian teoritis di mana teori kontrak sosial digunakan untuk menganalisis pertanggungjawaban pemerinatah/negara terhadap hak konstitusional warga negara secara luas. Teori kontrak sosial dipilih sebagai pisau analisis sebab erat kaitannya dengan objek penelitian ini, sebagaimana di atas telah di jelaskan bahwa kontrak sosial melahirkan sebuah kesepakatan tentang penyerahan kedaulatan rakyat kepada negara dan sebagai konsekuensi negara harus memenuhi apa yang menjadi hak daripada warga negara.

\section{PEMBAHASAN}

\section{Bentuk Tanggungjawab Negara Untuk Hak Konstitusional anak Terlantar}

Dalam Internasional yang mengatur tentang hukum HAM, definisi "pertanggungjawaban pemerintah/negara" erat kaitannya dengan kewajiban negara dalam memenuhi, melindungi dan menghormati HAM yang diakui secara universal. Membahas tanggung jawab negara, maka pasti kita sedang berbicara tentang hal penting suatu aturan karena sebuah aturan merupakan persyaratan utama yang bersifat mutlak untuk kehadiran atau ketiadaan pertanggungjawaban pemerintah dalam hal terjadi suatu kelalaian serta melawan hukum nasional maupun hukum internasional dalam konteks pemenuhan dan tanggung jawab negara terhadap HAM. ${ }^{13}$

Tanggung jawab Negara tidak dapat lepas dari pengaruh karakteristik tugas yang oleh Negara diberikan kepadanya. Pemerintah berkewajiban unutuk menjalankan dan mengikuti perintah Negara dalam menjalankan tugasnya, yaitu, untuk melaksanakan beberapa tugas negara sebagai organisasi kekuasaan. Tugas pemerintah, MacIver mengklasifikasikan dalam tiga fungsi, yaitu: (1) Fungsi Budaya, (2) fungsi walfare umum, (3) fungsi kontrol dalam bidang ekonomi. Konstitusi mewajibkan tanggungjawab pemerintah hendaklah sejalan dengan suatu tujuan dari berdirinya

\footnotetext{
13Zulfahmi, Perlindungan Terhadap Hak Konstitusional Anak Terlantar, JOM Fakultas Hukum, Vol. 1 Nomor 2, Oktober 2014. hlm, 2
}

240 HUKMY|Jurnal Hukum 
sebuah negara yang tertuang dalam Konstitusi pada bagian pembukaan UUD 1945 dengan tegas melindungi rakyat dan seluruh bangsa Indonesia serta memajukan adanya kesejahteraan yang bersifat umum, serta membagun intelektual anak bangsa. ${ }^{14}$

Ketentuan Konstitusi Pasal 34 (1) "Fakir miskin dan anak dengan kondisi terlantar dilindungi oleh pemerintah" negara memiliki pertanggungjawaban besar dalam memelihara serta memberi kesempatan kepada anak tersebut agar bisa berkembang sesuai dengan hak konstitusional yang melekat pada diri anak. ${ }^{15}$ Hak anak dengan kondisi terlantar dan hak anak yang tidak dalam keadaan terlantar posisinya adalah sama. Kesamaan ini jelas tertuang dalam uu ham 39/1999, kemudian termaktub dalam Kepres No. 36/1990 disebutkan bahwa, karena ketidakdewasaan fisik dan mental pada anak, oleh sebab itulah mereka membutuhkan simpati, empati, perlakuan serta perlindungan yang khusus dan tidak khusus. ${ }^{16}$

Pemeliharaan dan sifat melindungi pada anak merupakan salah satu bentuk tanggungjawab Negara supaya anak-anak bisa tumbuh lalu kemudian dapat berkembang sehingga dapat maksimal dalam berpartisipasi sesuai dengan martabatnya sebagai serta sebagai upaya untuk mendapatkan pengakuan dari sifat yang bernuansa kekerasan, serta perlakuan diskriminasi anak. UU 35 /2014 Pasal 4-18 merupakan salah satu bentuk perindungan terhadap anak dan hak-hak konstitusional anak guna menyelamatkan aset bangsa untuk masa depan negara dalam rangka mencapai sebuah ideolog bangsa, ${ }^{17}$ identitas dan posisi kewarganegaraan pada anak tersebut. ${ }^{18}$

UUD 1945 sebuah landasan atau pondasi bangsa Indonesia dalam menjalankan roda pemerintahan. Pendiri bangsa telah menetapkan UUD 1945 sebagai norma tertinggi dan menjadi batu uji terhadap UU dibawah UUD 1945. UUD 1945 sebagai hukum tertinggi telah diubah sebanyak empat kali pada tahun 1999, tahun 2000, dan tahun 2002 dan menghasilkan formulasi UUD NRI 1945 yang lebih kokoh dalam

\footnotetext{
${ }^{14}$ Ibid,

15Daya Negri Wijaya. Kontrak SosialMenurutThomas Hobbes Dan John Locke.JSPH Volume 1, Nomor 2, Desember 2016.hlm. 187

16Zulfahmi, Perlindungan Terhadap Hak Konstitusional Anak Terlantar, JOM Fakultas Hukum, Vol. 1 Nomor 2, Oktober 2014. hlm, 7

17 Dairani, D. (2021). Argumentasi Hukum Dan Upaya Mempertahankan Eksistensi Pancasila Sebagai Sumber Dari Segala Sumber Hukum Negara. HUKMY: Jurnal Hukum, 1(1), 19-34.hlm. 5

18Ibid, hlm. 9
} 
menjamin hak-hak konstitusional warga termasuk didalamnya ditegaskan posisi anak terlantar dan fakir miskin yang tertuang dalam Pasal 34 (1), disamping hal tersebut pemeliharaan terhadap anak terlantar juga selaras dengan pembukaan UUD 1945 yang berbunyi Pemerintah Indonesia melindungi yang bisa diartikan menjaga semua anak bangsa Indonesia dan turut serta dalam mensejahterakan masyarakat luas dan melaksanakan ketertiban dunia. ${ }^{19}$

Salah satu yang menjadi faktor adanya anak terlantar adalah karena faktor keluarga atau orangtua yang menelantarkan mereka sehingga anak tersebut tidak dapat tumbuh dan berkembang dengan maksimal karena kebutuhan dasar mereka tidak lagi terpenuhi. ${ }^{20}$ Disamping tidak memberikan kebutuhan dasar anak salah satu bentuk dari penelantaran anak adalah mengabaikan keinginan dan kebutuhan anak, membiarkan anak melakukan hal-hal yang negatif yang berpotensi merugikan terhadap dirinya sendiri, bangsa dan Negara. ${ }^{21}$ Mengabaikan anak dari pemenuhan gizi, tidak memberi perhatian terhadap anak dan yang banyak terjadi yang berakibat fatal adalah tidak memberikan atau mengenalkan anak pada pendidikan. ${ }^{22}$

Anak terlantar atau terabaikan, pada dasarnya yaitu "anak-anak", yang tidak beda dengan anak yang lain yang posisinya tidak terbaikan yang hak dan kewajibannya sama dalam konteks sebagai warga negara. Mereka anak terlantar membutuhkan pendidikan. Namun dalam hal memberikan pendidikan harus disesuaikan dengan dunianya anak sebab anak punya kehidupan dunia sendiri yang pada umumnya tidak sama dengan anak yang sudah dewasa. Pendidikan pada anak terlantar menjadi kebutuhan mutlak sebab dengan pendidikan itu anak akan dapat memahami dan bisa membawa dirinya menjadi lebih baik. ${ }^{23}$ Dalam catatan peneliti, pendidikan menjadi persoalan mendasar yang di alami anak terlantar di Indonesia hal ini tidak lepas dari beberap afaktor missal: pertama, tidak adanya biaya; kebanyakan anak yang terabaikan biasanya berangkat dari kondisi ekonomi keluarganya yang tidak mampu atau

\footnotetext{
${ }^{19}$ Undang-Undang Republik Indonesia Nomor 4 Tahun 1979 tentang Kesejahteraan Anak dan UndangUndang Republik Indonesia Nomor 23 tahun 2002 sebagaimana telah di ubah dengan Undang-undang Nomor 35 Tahun 2014 tentang Perlindungan Anak.

${ }^{20}$ Zulfahmi, Perlindungan Terhadap Hak Konstitusional Anak Terlantar, JOM Fakultas Hukum, Vol. 1 Nomor 2, Oktober 2014. hlm, 9

${ }^{21} \mathrm{Ibid}$,

${ }^{22}$ Ibid,

${ }^{23}$ Imam Sukadi, Tangung Jawab Negara Terhadap Anak Terlantar, de jure, Jurnal Syariah dan Hukum, Vol. 5 Nomor 2, Desember 2013, hlm, 127
}

242 HUKMY|Jurnal Hukum 
beradapa pada garis kemiskinan, sebagai akibat, keluarga tidak sanggup dan tidak cukup mampu menyediakan biaya pendidikan anak; kedua, keterbatasan waktu dari anak itu sendiri, sebab guna memenuhi kebutuhan dasar hidupnya mereka harus bekerja apa saja agar kebutuhannya dapat terpenuhi bahkan juga tidak jarang dalam kenyataannya pelaku pencurian dan pencopet berasal dari kalangan anak-anak sehingga waktu mereka habis untuk mencari suaka guna memenuhi kebutuhan hidupnya. ${ }^{24}$

Ketiga, Rendahnya minat dan keinginan untuk belajar; keadaan ini disebabkan oleh beberapa faktor disamping faktor dukungan dari keluarga juga tidak lepas dari pengaruh lingkungan tempat anak terlantar bermain. Jika ia bermain dengan mereka yang tidak bersekolah maka tidak sekolah formal tidak akan menjadi sesuatu yang patut disesali dikemudian hari. Keempat, Apatisme terhadap pendidikan, yang disebabkan oleh berfikir pendek dalam menghasilkan uang. Dalam anggapan mereka sekolah tidak lantas menjadikan mereka mendapatkan uang dengan cepat maka mereka berfikir bahwa tanpa sekolahpun mereka bisa menghasilakan uang. Kelima, macetnya atau tidak berfungsinya pengawasan dan kontrol dari keluarga, pemerintah, masyarakat dan teman yang mereka disibukkan dengan kesibukan masing-masing. ${ }^{25}$

Selain masalah pendidikan di atas, teradapat masalah yang tidak kalah penting yaitu terkait masalah kesehatan pada anak-anak terlantar. Mengingat keadaan dan kondisi yang mereka tempati merupakan tempat yang berada dalam kategori tidak layak huni bagi manusia, dengan tempat seadanya membuat mereka dingin ketika musim hujan dan panas disaat musim kemarau tiba, inilah salah satu potret kemiskinan yang terjadi di Indonesia yang juga berdampak pada adanya anak terlantar semakin banyak jumlahnya tentunya hal ini menjadi salah satu bukti gagalnya Negara dalam menjamin kesejahtraan terhadap waganya dimana kesejahteraan dan hidup layak merupakan hak konstitusional warga Negara.

Diantara persoalan-persoalan yang terjadi pada anak yang terabaikan dapat dikategorikan dibawah ini: ${ }^{26}$

\footnotetext{
${ }^{24}$ Ibid, hlm, 128

${ }^{25}$ Ibid, hlm 129

${ }^{26}$ Ibid, hlm 130
} 
1. Desakan ekonomi pada keluarga seorang anak menjadi penyebab anak tersebut keluar dari rumah kemudian menjadi penghuni jalanan;

2. Tingkat pengetahuan dan Pendidikan yang rendah orangtua menjadi faktor kedua;

3. Tidak tersedianya kebijakan dari pemerintah yang langsung bersentuhan dengan anak terlantar;

4. Kontrol sosial masyarakat yang tidak berfungsi sebagaimana seharusnya;

5. Peran organisasi sosial yang rendah;

6. Kreatifitas dan potensi anak terlantar tidak mendapat tempat dan apresiasi yang baik bagi pemerintah dan masyarakat.

Pembinaan, pemeliharaan anak dengan kondisi terlantar tanggungjawabnya berapada pada pemerintah dan negara berdasarkan mandate konstitusi. Kewajiban tersebut dapat berbentuk adanya perlindungan hukum terhadap anak sesuai dengan uu No. 35/2014 dianatara bentuk kewajiban tersebut adalah:

1. Berdasarkan Pasal 21, Negara dan atau pemerintah bertanggung jawab dalam menghormati, melindungi, dan menjamin HAM tiap anak bangsa dengan tidak membedakan sukunya, agama, ras dan golongannya, juga tidak pula berdasarkan jenis keminnya, etniknya, bahasa dan budayanya, status hukum, waktu lahirnya anak, dan keadaan dan psikologi pada anak;

2. Ketentuan Pasal 22 pemerintah berkewajiban dan punya tanggung jawab untuk memberi dukungan beruapa fasilitas untuk proses pelaksanaan dalam melindungi anak;

3. Ketentuan Pasal 23 (1) adanya jaminan berupa perlindungan, keadaan ekonomi yang tercukupi dengan tetap hak dan kewajiban orangtua anak menjadi perhatian. Ayat (2) pemerintah mengawasasi penyelenggaraan perlindungan anak secara berkala;

4. Ketentuan Pasal 24 Negara wajib memberikan jaminan pada anak supaya menunaikan haknya didalam memberi pendapat yang sesuai dengan usianya dan berdasarkan pada kecerdasan intelektual masing-masing anak;

Berdasar pada uraian di atas, negara dalam ini adalah Pemerintah sebagai penyelengara urusan pemerintahan tidak hanya harus mampu, namun juga wajib hukumnya untuk melaksanakan mandat konstitus dalam kaitannya dengan bentuk 
perlindungan, pertanggungjawaban terhadap fakir miskin serta anak yang berada pada kondisi terabaikan atau terlantar. Sebab persoalan kemiskinan dan keberadaan anak jalanan atau terabaikan menjadi persoalan serius yang butuh penagangan serius pula dari pemerintah berikut elment-elmentnya pemerintah baik pusat hingga ditingkat daerah atau wilayah.

Namun demikian meski secara konstitusi, mandataris penanganan anak dengan kondisi terlantar atau terabaikan adalah tanggungjawab negara. Namun secara umum dalam kontesk kehidupan bernegara kondisi tersebut adalah tanggungjawab bersama, tanggungjawab bersama ini menyangkut keluarga, masyarakat umum, pengambil atau pembuat kebijakan, tokoh agama dan ujung daripada penanggungjawab persoalan ini adalah negara sesuai dengan mandat konstitusi Pasal 34 (1), uu 35/2014. Uu 39/1999 sebagai dasar hukum lahirnya taggungjawab tersebut terhadap negara. Sehingga dengan bersama-sama dan bergotong royong dalam menangani dan mengatasi persoalan di atas, keberadaan fakir miskin dan anak jalanan yang terlantar tidak lagi ditemukan, dan mereka sudah selayaknya menikmati-hak-haknya yang secara tegas dilindungi oleh konstitusi.

\section{Strategi Negara mengatasi Persoalan Anak Terlantar di Indonesia: Manifestasi Tanggung Jawab Negara}

Anak terlantar diidentikkan dengan kemiskinan, bertambahnya keluarga miskin juga merupakan faktor berkembangnya populasi anak terlantar. Kemiskinan menyebabkan munculnya pengemis maupun gelandangan. Keberaan anak Anak pada kondisi terlantar tidak jarang dijadikan satu kesempatan untuk dimanfaatkan guna mendapatkan keuntungan bagi oknum tertentu yang hanya memikirkan kesejehteraanya senidiri, kelompok da golongannya. Salah satu contoh dari pemanfaatan anak oleh oknum yang tidak bertanggungjawab adalah menjadikan anak tersebut sebagai pengemis untuk kemudian hasilnya diambil oleh oknum tak prikemanusiaan tadi. Padahal anak pada posisi tersebut tidak seharusnya diperlakukan demikian, sebab anak pada dasarnya memiliki hak untuk diperlakukan baik sebagai 
manusia sehingga ia dapat berkembag layaknya anak pada umumnya, terpenuhi hak pendidikannya. Kesehatannya dan hak-hak dasar yang melekat pada anak. ${ }^{27}$

UNICEF membedakan anak terlantar ke dalam dua kategori, yaitu: (1) Children on the street, yang masuk dalam kategori pertama ini merupakan anak yang berada pada garis keturunan langsung dari orangtuaya. (2) Children of the street, sedangkan yang masuk dalam kategori kedua ini adalah anak yang sudah tidak mempunyai hubungan dengan keluarga maupun orang tua. ${ }^{28}$ Doktrin tentang kedaulatan dan kesamaan hak menghasilkan internastional law menegaskan bahwa memenuhi hak anak yang bersifat fundamental sepenuhnya merupakan tanggung jawab dari negara. Dengan diratifikasinya Conventions on the Right of the Child maka timbul suatu kewajiban negara guna berbuat sesuatu, khususnya terkait perlindungan dan pemiliharaan anak terlantar. Walaupun sudah banyak pengaturan terkait perlindungan dan pemeliharaan anak namun realitanya, masih banyak ditemukan keadaan anak dalam kondisi terlantar dan mendapatkan perlakuan yang tidak berprikemanusiaan tidak hanya fisiknya namun juga secara psikis. Banyak berita di media massa tentang persoalan yang terjadi pada anak-anak bangsa dalam hal ini adalah anak yang terbaika. Misalnya kasus eksploitasi, kekerasan dan pengeniayaan pada anak yang pelakunya lebih banyak dari keluarga anak tersebut. ${ }^{29}$

Persoalan terkait penengangan anak terlantar memang semata-mata kewajiban negara. Diperlukan adanya sinergi dan gotong royong antara tiga element, yaitu negara, pihak swasta dan masyarakat madani (civi society) merupakan hal yang sangat fundamental dalam mengatasi persoalan anak terlantar di Indonesia. oleh karenanya peran ketiganya sangat diperlukan dalam perlindungan dan pemeliharan anak terlantar.

Negara atau pemerintah memerlukan adanya best practice di dalam merumuskan suatu kebijakan, misalnya negara memerlukan konsultan khusus yang tugasnya juga khusus mengkaji persoalan dan menemukan solusi atau formulasi hukum yang tepat dalam mengatasi problematika anak yang keberadaanya terlantarkan.

\footnotetext{
27 Imam Sukadi, Op. Cit, 118.

28 Abd Chayyi Fanani, Pesantren Anak Jalanan, (Surabaya: Penerbit Alpha, 2008), 35.

29 Imam Sukardi, Gatot Sapto Heriyawanto, dan Mila Rahayu Ningsih, Perlindungan Hukum Terhadap Anak Terlantar dalam Perpektif Negara Kesejahteraan, Qawwam: Journal for Gender Mainstreaming Vol. 14, No. 2, (2020), 33.
}

\section{HUKMY|Jurnal Hukum}


Strategi pemberdayaan merupakan langkah tepat dalam pembangunan SDM yang bermuara pada persoalan mengatasi keberadaan anak yang terabaikan. Strategi selanjutnya yang bisa lakukan oleh negara adalah dengan Dengan memaksimalkan serta meningkatkan fungsi berbagai lembaga pemerintah khususnya pada lembaga sosial pusat maupun lokal untuk membuat langkah atau trobosan konkrit dalam mengentas anak dari jalanan serta langkah tersebut juga harus berorentasi pada keberhasilan penangangan kesejahteraan umum diberbagai di wilayah Indonesia. ${ }^{30}$

\section{KESIMPULAN}

Keberadaan anak terlantar menjadi salah satu persoalan serius disamping beberapa persoalan lain di Indonesia. Data Menteri Sosial pada Desember 2020 anak terlantar sejumlah 67.368. tentu ini menjadi masalah serius yang harus segera diselesaikan. Ketentuan Pasal 34 (1) menegaskan secara konstitusi negara bertanggungjawab atas persoalan tersebut. Konstitusi menyebut bahwa keberadaan fakir fiskin serta anak jalanan atau terlantar dipelihara oleh negara. Hal dapat diartikan bahwa negara berkewajiban untuk melindungi, memelihara dan memberikan hak-hak dasar konstitusional daripada anak terlantar tersebut layaknya hak anak pada umumnya. Kewajiban negara atas persoalan tersebut juga tertuag dalam uu No. 35/2014 pada Pasal 21, Pasal 22, Pasal 23 dan Pasal 24.

Guna mengatasi persoalan di atas, negara wajib membuat langkah-langkah strategis diantaranya adalah pertama, mengangkat konsultan khusus yang tugasnya secara khusus mengkaji persoalan dan menemukan solusi atau formulasi hukum yang tepat dalam mengatasi problematika anak yang keberadaanya terlantarkan. Kedua, peningkatan pembangunan SDM anak masyarakat khsususnya pada keluarga yang berada pada garis kemiskinan sebab kemiskinan menjadi salah satu penyebab adanya anak terlantar. Langkah ketiga, Memaksimalkan serta meningkatkan fungsi berbagai lembaga pemerintah khususnya pada lembaga sosial pusat maupun local untuk membuat langkah atau trobosan konkrit dalam mengentas anak dari jalanan serta

30 Chairun Nasirin, Program Pemberdayaan Anak-Anak Terlantar di Nusa Tenggara Barat, Sosio Humaniora, Vol. 15, No. 3, (November 2013), 243. 
langkah tersebut juga harus berorentasi pada keberhasilan penangangan kesejahteraan umum.

\section{DAFTAR PUSTAKA}

Chairun Nasirin, Program Pemberdayaan Anak-Anak Terlantar di Nusa Tenggara Barat, Sosio Humaniora, Vol. 15, No. 3, (November 2013

Chayyi, Abd Fanani. Pesantren Anak Jalanan Surabaya: Penerbit Alpha. 2008

Dairani, D. Argumentasi Hukum Dan Upaya Mempertahankan Eksistensi Pancasila Sebagai Sumber Dari Segala Sumber Hukum Negara. HUKMY: Jurnal Hukum, 1(1), 2021

Daya Negri Wijaya. Kontrak SosialMenurutThomas Hobbes Dan John Locke. JSPH Volume 1, Nomor 2, Desember 2016

Fifk Wiryani, Perlindungan Hukum Bagi Pekerja Anak, Jurnal Legality, Vol. 11 No. 2 September 2003- Februari 2004

Hadjon, Philipus M. Perlindungan Hukum Bagi Rakyat Indonesia, Surabaya: Bina Ilmu. 1987

Ibad, S. Hukum Administrasi Negara Dalam Upaya Penyelenggaraan Pemerintahan Yang Baik. Hukmy: Jurnal Hukum. Vol. 1, (1) April 2021. https://doi.org/10.35316/hukmy.2021.v1i1.55-72

Imam Sukardi, Gatot Sapto Heriyawanto, dan Mila Rahayu Ningsih, Perlindungan Hukum Terhadap Anak Terlantar dalam Perpektif Negara Kesejahteraan, Qawwam: Journal for Gender Mainstreaming Vol. 14, No. 2, 2020

Jihan Thania Damayanti Safitri. Dkk. Tanggung jawab negara terhadap hak konstitusional anak terlantar di indonesia. Lex Privatum Vol. IX/No. 4/Apr/EK/2021

Suryanto, Bagong. Masalah Sosial Anak. Jakarta: Kencana Prenada Media Group. 2010

Zulfahmi, Perlindungan Terhadap Hak Konstitusional Anak Terlantar, JOM Fakultas Hukum, Vol. 1 Nomor 2, Oktober 2014 